\title{
Mechanical Thrombectomy in ST-segment Elevation Myocardial Infarction
}

\author{
Luka Bastiančić*, \\ Gordana Bačić, \\ David Gobić, \\ Tomislav Jakljević \\ University of Rijeka School \\ of Medicine, University \\ Hospital Centre Rijeka, \\ Rijeka, Croatia
}

KEYWORDS: mechanical thrombectomy, primary PCI, ST-segment elevation myocardial infarction. CITATION: Cardiol Croat. 2016;11(3-4):95. | DOI: http://dx.doi.org/10.15836/ccar2016.95

*ADDRESS FOR CORRESPONDENCE: Luka Bastiančić, Klinički bolnički centar Rijeka, T. Strižića 3, HR-51000 Rijeka, Croatia. / Phone: +385-51-407-111 / E-mail: Ibastiancic@hotmail.com

ORCID: Luka Bastiančić, http://orcid.org/0000-0002-6520-0287 • Gordana Bačić, http://orcid.org/0000-0002-9050-5314 David Gobić, http://orcid.org/0000-0001-9406-1127 • Tomislav Jakljević, http://orcid.org/0000-0002-3692-0111

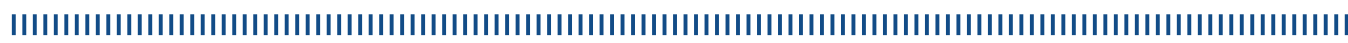

Introduction: Occlusive thrombus due to ruptured or eroded atherosclerotic plaque is the most frequent substrate for ST-segment elevation myocardial infarction (STEMI). Distal embolization of intracoronary thrombus results in microvascular obstruction and compromised TIMI (Thrombolysis In Myocardial Infarction) flow. Forceful coronary injections, passage of intracoronary devices, initial balloon angioplasty and/or stenting induce distal embolization. Intracoronary thrombus additionally may contribute to vessel and stent undersizing increasing the risk of stent malapposition, in-stent restenosis or stent thrombosis. ${ }^{1-3}$

Case presentation: We present an 81-year-old Caucasian male with STEMI with rapid progression to cardiogenic shock and cardiorespiratory arrest during diagnostic coronary angiography. Severe stenosis of right coronary artery (RCA) with occlusive thrombus of the left main (LM) was found. The patient received a veno-arterial extracorporeal membrane oxygenation (ECMO) device. We performed a standard percutaneous coronary intervention (PCI) of RCA and rheolytic thrombectomy (Angio Jet ${ }^{\text {TM}}$ ) of the LM. The patient was successfully weaned from ECMO 29 hours after the procedure, with no inoconstrictor support. After nine days he was fully mobilized with no neurological deficit and a $40 \%$ left ventricular ejection fraction on echocardiography.

Conclusion: Current evidence does not support the routine use of rheolytic thrombectomy in primary PCI. In specific cases that are involving large occlusive thrombus it may be a therapy of choice.

LITERATURE IIIIIIIIIIIIIIIIIIIIIIIIIIIIIIIIIIIIIIIIIIIIIIIIIIIIIIIIIIIIIIIIIIIIIIIIIIIIIIIIIIIIIIIIIIIIIIIIIIIIIIIIIII

1. Parodi G, Valenti R, Migliorini A, Maehara A, Vergara R, Carrabba N, et al. Comparison of manual thrombus aspiration with rheolytic thrombectomy in acute myocardial infarction. Circ Cardiovasc Interv. 2013;6(3):224-30. DOI: http://dx.doi.org/10.1161/CIRCINTERVENTIONS.112.000172

2. Beran G, Lang I, Schreiber W, Denk S, Stefenelli T, Syeda B, et al. Intracoronary thrombectomy with the X-sizer catheter system improves epicardial flow and accelerates ST-segment resolution in patients with acute coronary syndrome: a prospective, randomized, controlled study. Circulation. 2002;105:2355-60. DOI: http://dx.doi.org/10.1161/01.CIR.0000016350.02669.1D

3. Antoniucci D, Valenti R, Migliorini A, Parodi G, Memisha G, Santoro GM, et al. Comparison of rheolytic thrombectomy before direct infarct artery stenting versus direct stenting alone in patients undergoing percutaneous coronary intervention for acute myocardial infarction. Am J Cardiol. 2004;93:1033-5. DOI: http://dx.doi.org/10.1016/j.amjcard.2004.01.011 